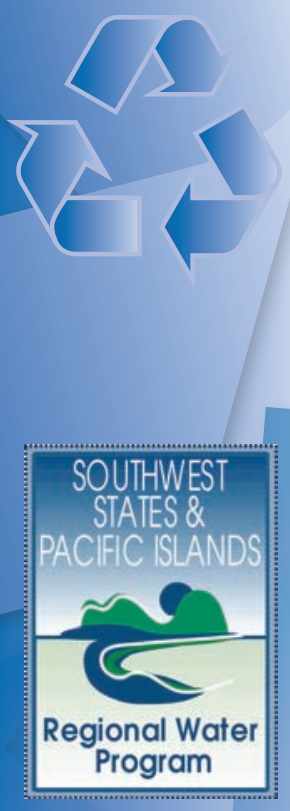

\title{
Safe Application of Reclaimed Water Reuse in the Southwestern United States
}

LAOSHENG WU, University of California Cooperative Extension Water Management Specialist, UC Riverside; WEIPING CHEN, Research Associate, UC Center for Water Resources; CHRISTINE FRENCH, Program Analyst, UC Center for Water Resources; ANDREW CHANG, Director Emeritus, UC Center for Water Resources

\section{INTRODUCTION}

In the arid and semiarid southwestern United States, the land and the people thirst for more water. The reclamation era of the 1930s to 1960s saw the construction of infrastructure for storing and conveying water by the federal government that greatly aided the development of America's West. With the increase in available water, more land was put into production and more people moved west. As the population continues to grow, increased demands are being placed on water resources for urban, agricultural, and environmental needs.

The California Department of Water Resources (DWR) projects that the state's population will grow by 17 million people over the next 25 years, catapulting to 52 million by 2030 (DWR 2005). Urban water demands are expected to rise by 47 percent, yet agricultural and environmental needs are expected to hold steady. U.S. Census Bureau estimates show that populations in both Arizona and Nevada are expected to double by 2030 (from 2000 totals), adding an additional 7 million people to those two states. This will put further demands on the region's water resources.

The readily available sources of water in the Southwest have been exhausted. Costs of bringing additional water on line, if available, would be prohibitively expensive. While options for developing water supplies via traditional approaches are limited, municipal wastewater is readily available, as it is produced at the proximity of the demands, is reliable, and may be treated to meet required standards at a reasonable cost.

With the discharge requirements stipulated by the federal Clean Water Act (CWA, 1972), reclaimed wastewater has been steadily improving in quality and is increasingly being recognized as a potential source of water supply. Water pollution control efforts implemented around the world since the 1960s are producing large volumes of treated municipal wastewater effluent that are, for the most part, currently discharged to surface water bodies or to the oceans. Water reclamation, recycling, and reuse are now recognized worldwide as key components in the efficient management of water resources. Arizona, California, and Nevada have promulgated regulations and established programs that strongly encourage water reuse as a strategy for water resources conservation. 


\section{Water Reuse Opportunities}

With advances in technology, wastewater may be treated to meet the most stringent quality requirements and can be used for any purposes desired. The potential uses for reclaimed water are indeed numerous and widely varied (fig. 1); however, reclaimed water has been used most commonly for nondirect consumption and non-body-contact purposes.

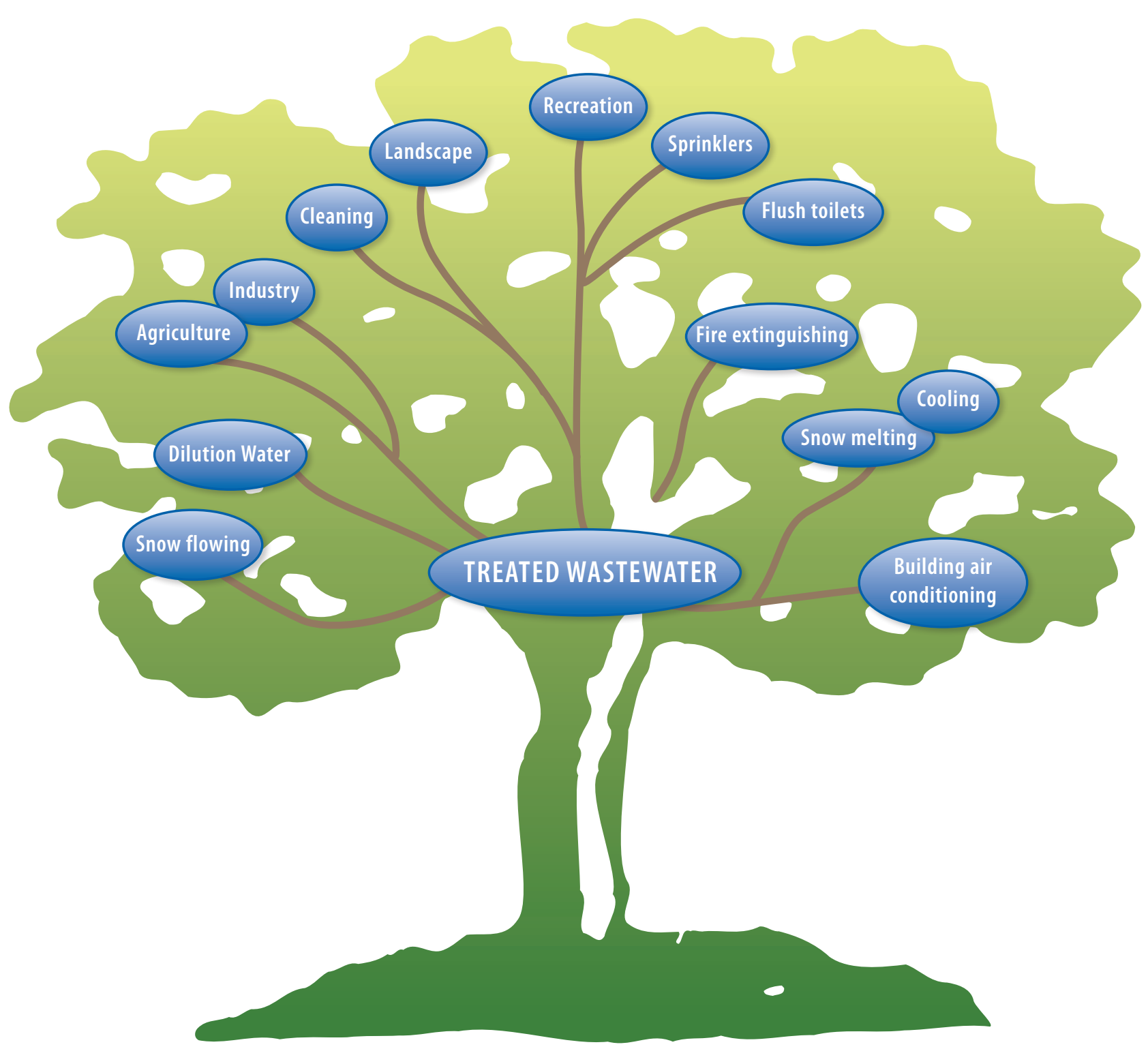

Figure 1. Wastewater reuse opportunities. Source: After MLIT 2001. 


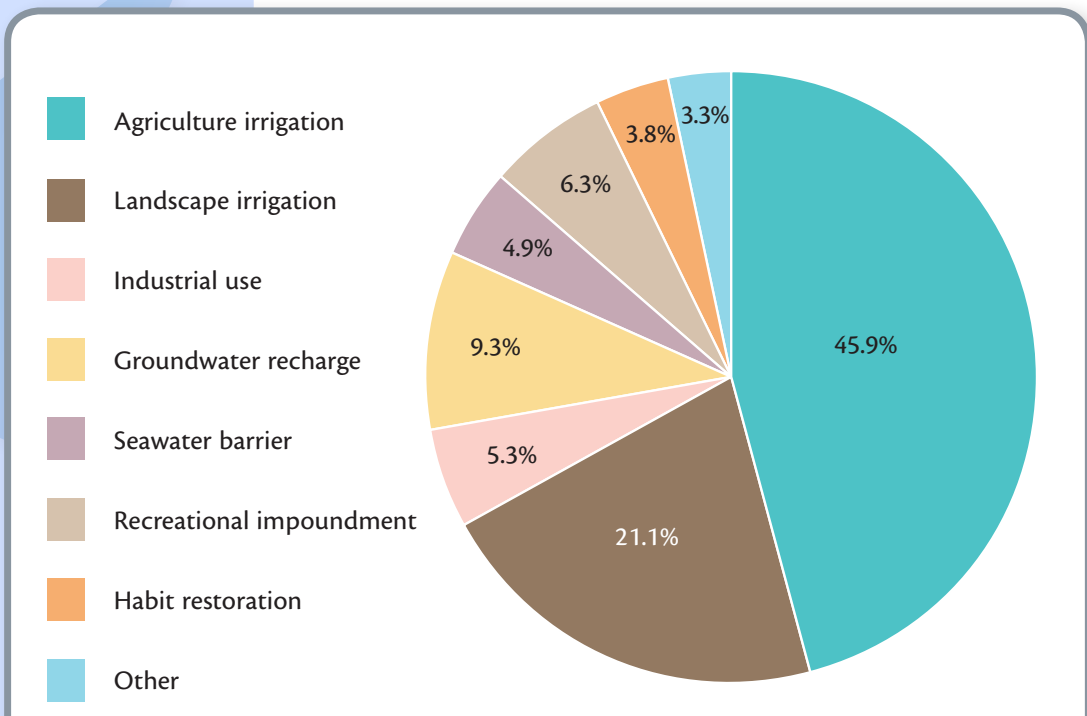

Figure 2. Wastewater reuse in California. Source: CSWRCB 2003.

\section{Water reuse in the Southwest}

Water recycling in California is an integral part of the water management plan, and over 500,000 acrefeet $(\mathrm{AF})$ of reclaimed water is put to beneficial use annually (CSWRCB 2003). (For metric and English equivalents, see the table at the end of this publication.) The most common uses are for agricultural and landscape irrigation (fig. 2).

The Arizona Department of Water Resources has established five active management areas (AMAs) charged with management and conservation of groundwater resources as well as finding viable options to supplement current water supplies. While the AMAs cover only 13 percent of Arizona's land area, 80 percent of the population live within these areas. Each AMA is using reclaimed wastewater to meet their charge. In 2003, 244,000 acre-feet of reclaimed water was reported to be put to beneficial uses within the five AMAs; of that total, agricultural and landscape irrigation accounted for approximately 48 percent of the usage (29\% agricultural irrigation, $28 \%$ industrial use, $24 \%$ groundwater recharge, $19 \%$ landscape irrigation) (for more detailed information, see ADWR 1999). Reclaimed water is also being used in areas outside the AMAs; however, that use has not yet been quantified.

In southern Nevada, reclaimed water is being used to control dust at landfills and at sand and gravel operations, as a coolant for power generation plants, and for irrigation of golf courses, highway landscaping, and parks. In 2004, agencies within the Southern Nevada Water Authority used approximately 24,000 acre-feet of reclaimed water for these purposes (SNWA 2006).

\section{Objectives}

The objectives of this publication are to provide up-todate knowledge about

- federal and state regulations and guidelines on water reuse

- physical, chemical, and biological characteristics of reclaimed wastewaters

- the safe application of wastewater for landscape and agriculture

\section{Federal and State Regulations and GUIDELINES ON WASTEWATER REUSE}

To ensure public health and safety, reclaimed waters are often subject to rigorous regulatory controls, including defined levels of treatment, set numerical limits for water quality, and qualitative control factors such as process reliability requirements. In the United States, regulations governing water reuse may be described as a tiered system that begins with requirements decreed by federal legislation and works its way down to local ordinances and codes.

No federal regulations directly govern water reuse practices in the United States. Water reuse regulations and guidelines have, however, been developed by 25 states including Arizona, California, and Nevada; an additional 16 states have guidelines or design standards, leaving only 9 states with no regulations or guidelines. Contents of the regulations and guidelines vary considerably from state to state. States such as Arizona, California, and Nevada have developed regulations or guidelines that strongly encourage reuse as a water conservation strategy. Their regulations or guidelines specify water quality requirements, treatment processes, or both, for the full spectrum of reuse applications. The objective of these regulations is to derive the maximum resource benefits of the reclaimed water while protecting the environment and public health.

\section{Federal Jurisdiction}

Although no formal statute at the federal level specifically covers the use of recycled water, the Clean Water Act provides the umbrella legislative mandate that covers all forms of effluent discharges from publicly owned treatment works (POTW, or wastewater treatment plants). The CWA requires industries that discharge wastewater into municipal sewers to comply 
with prescribed industrial pretreatment requirements, meet preset treatment performance standards, and obtain permits for discharging effluent. The two programs under the Clean Water Act that are most relevant to water treatment and reuse are the Industrial Wastewater Pretreatment Program and the National Pollutant Discharge Elimination System (NPDES) Program.

The Industrial Wastewater Pretreatment Program requires industrial dischargers to treat their discharge water to a level that will not cause disruption of the POTW's treatment system prior to discharging to the sanitary sewer system. The enactment of this program protects the efficiency of POTW treatment and enables reclaimed water to be used without undue water quality limitations.

The NPDES program (permit) sets limits on water quality constituents and is required for any discharges to the nation's waterways. All federally funded wastewater treatment for reuse projects must comply with provisions listed in the NPDES program. Forty-five states have been delegated the authority of issuing NPDES permits. These states or their agencies may elect to adopt the federally mandated requirements or impose more stringent pollutant discharge standards.

The authorized state agencies, such as the California State Water Resources Control Board (SWRCB) along with its Regional Water Quality Control Boards (RWQCB), the Arizona Department of Environmental Quality (ADEQ), and the Nevada Division of Environmental Protection Bureau of Water Pollution Control (BWPC) have the authority to issue or deny a permit based on information submitted by the permit applicant. Public input through hearings may be required prior to the regulator's adoption or denial of the permit application; issued permits must be renewed or reissued every 5 years.

\section{State Water Reuse Regulations}

\section{Regulatory authority}

States hold the primary responsibility for regulating water reuse in the United States. However, the jurisdiction of regulating water reuse may be contained within a single agency or may be divided among several agencies. In California, each of the nine RWQCBs is responsible for issuing effluent discharge permits either under the authorization of the NPDES program (discharge of treated effluent to a stream, river, or ocean) or the waste discharge requirements (discharge of treated effluent to land, such as reclaimed water for irrigation purposes). Rules and regulations for the end use of recycled water are established and enforced by each RWQCB, the California Department of Public Health (DPH) and the local city or county health department. These rules and regulations are typically contained in a permit from the regional board issued to the individual recycled water agency or producer (see California Code of Regulations Title 22, Chapter 3, Reclamation Criteria).

The Arizona Department of Environmental Quality requires water reuse projects to obtain the Reclaimed Water Individual Permit or Reclaimed Water General Permit (see Arizona Administrative Code, Title 18, Chapter 9, articles 6 and 7; and Chapter 11, article 3). An individual discharge permit is required for the reuse of industrial wastewater that contains a component of sewage or is used in processing any crop or substance that may be used as human or animal food. To encourage water reuse, nine general discharge permits that outline the requirements for different classes of reuse have been established. Permits are granted to operators who can demonstrate meeting the requirements specified in the general discharge permits. Among the 9 permits, 2 cover gray water (water from clothes washers, bathtubs, showers, and baths, not from kitchen sinks, dishwashers, or toilets); 1 covers the reclaimed water agent; 1 covers the reclaimed water blending facility; and 5 cover the end users based on the reclaimed water class. The processes for general discharge permits take less time to complete and require lower review fees than the individual discharge permit.

The Nevada Division of Environmental Protection (NDEP) must be contacted when water reuse is planned. NDEP will determine the appropriate discharge permit and assist the applicants in preparing the design submittal. Prior to granting the permit, NDEP conducts a comprehensive review of the plans for the reclaimed water use project that are prepared and certified by registered professional engineers in Nevada. To address issues related to secondary water rights, the Nevada Division of Water Resources (NDWR) must be consulted. Finally, the Nevada State Health Division (NSHD) should also be consulted to ensure that the plan is consistent with water supply protection requirements.

\section{Reclaimed water quality and treatment requirements}

Arizona, California, and Nevada have set standards for reclaimed water quality or have specified minimum treatment requirements that are dependent on the end uses of the water. When unrestricted public exposure is likely to take place during the course of reuse, 
reclaimed water must meet stringent quality standards and performance levels. When there is no public exposure, the quality standards and the treatment levels may be relaxed (table 1). Biochemical oxygen demand (BOD), total suspended solids (TSS), and total or fecal coliform counts are the most common water quality parameters for which the upper thresholds are imposed, with biological oxygen demand and total suspended solids serving as indicators for the adequacy and reliability of the treatment, and total or fecal coliform counts as an indicator of the extent of disinfection through the treatment process. Total or fecal coliform is considered in order to minimize the exposures to pathogenic organisms.
In addition to the use categories summarized in table 1, California has separate rules pertaining to groundwater recharge and industrial reuse of reclaimed wastewater. The required wastewater treatment processes are not specified; instead, DPH evaluates all relevant aspects of a proposed project, including treatment provided, effluent quality and quantity, nature of the spreading operation, soil characteristics, hydrogeology, residence time, and travel distance to point of withdrawal. Requirements for the project are then determined based on the evaluation findings.

No specific requirements exist in Arizona, California, or Nevada for reclaimed water used for environmental purposes of enhancing or maintaining aquatic ecosystem functions and services.

Table 1. Wastewater reuse criteria of Arizona, California, and Nevada

\begin{tabular}{|c|c|c|c|c|}
\hline Use category & Parameter & Arizona & California & Nevada \\
\hline \multirow{5}{*}{$\begin{array}{l}\text { unrestricted urban } \\
\text { reuse; agricultural reuse: } \\
\text { food crops; unrestricted } \\
\text { recreational reuse }\end{array}$} & treatment level & $\begin{array}{l}\text { secondary treatment, } \\
\text { filtration, and disinfection }\end{array}$ & $\begin{array}{l}\text { oxidized, coagulated, } \\
\text { filtered, and disinfected }\end{array}$ & $\begin{array}{l}\text { secondary treatment and } \\
\text { disinfection }\end{array}$ \\
\hline & BOD5 (mg/l) & NS & NS & 30 \\
\hline & turbidity (NTU) & average 2 ; maximum 5 & average 2 ; maximum 5 & NS \\
\hline & $\begin{array}{l}\text { fecal coliform } \\
\text { (MPN/100 ml) }\end{array}$ & $\begin{array}{l}\text { average: not available; } \\
\text { maximum } 23\end{array}$ & NS & $\begin{array}{c}\text { average } 2.2 \text {; maximum } 23^{*} \text {; average } \\
200 \text {; maximum } 400^{\dagger}\end{array}$ \\
\hline & $\begin{array}{l}\text { total coliform } \\
\text { (MPN/100 ml) }\end{array}$ & NS & $\begin{array}{l}\text { average } 2.2 ; 30 \text {-day } \\
\text { maximum } 23\end{array}$ & NS \\
\hline \multirow{4}{*}{$\begin{array}{l}\text { restricted urban } \\
\text { reuse; nonfood crop } \\
\text { irrigation; restricted } \\
\text { recreational reuse }\end{array}$} & treatment level & $\begin{array}{l}\text { secondary treatment and } \\
\text { disinfection }\end{array}$ & $\begin{array}{l}\text { secondary, oxidized, and } \\
\text { disinfected }\end{array}$ & $\begin{array}{l}\text { secondary treatment and } \\
\text { disinfection }\end{array}$ \\
\hline & BOD5 (mg/l) & NS & NS & 30 \\
\hline & $\begin{array}{l}\text { fecal coliform } \\
\text { (MPN/100 ml) }\end{array}$ & average 200; maximum 800 & NS & $\begin{array}{c}\text { average } 23 \text {; maximum } 240^{\ddagger} \text {; average } \\
200 \text {; maximum } 400^{\S}\end{array}$ \\
\hline & $\begin{array}{l}\text { total coliform } \\
\text { (MPN/100 ml) }\end{array}$ & NS & $\begin{array}{l}\text { average } 23 ; 30 \text {-day maxi- } \\
\text { mum } 240^{*} \text {; average } 2.2 ; \\
30 \text {-day maximum } 23^{* *}\end{array}$ & NS \\
\hline
\end{tabular}

Key: $\mathrm{BOD}=$ biological oxygen demand; $\mathrm{MPN}=$ most probable number; $\mathrm{NS}=$ not specified; $\mathrm{NTU}=$ nephelometric turbidity units.

Notes:

*Apply to unrestricted urban reuse and unrestricted recreational reuse.

${ }^{\dagger}$ Apply to agricultural reuse-food crops.

${ }^{\ddagger}$ Restricted urban and recreational reuses.

${ }^{\S}$ Agricultural reuse-nonfood crops.

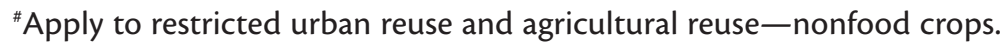

**Restricted recreational reuse. 


\section{Site management practices}

Water quality monitoring. The quality of reclaimed wastewater slated for reuse is routinely monitored on a quarterly, monthly, weekly, daily, or continuous basis depending on the constituents. For example, daily sampling for fecal coliform is required for unrestricted urban reuse in Arizona, while monthly sampling is sufficient for nonfood crop irrigation. The turbidity of the finished water is often continuously monitored in real time, as is required in California.

Treatment facility reliability. Treatment plants producing reclaimed water may be required to implement provisions to ensure reliability of processing. These provisions include alarms to warn of power failure, automatic standby power source, emergency storage, and redundancy or backup units. California's reclamation criteria (see California Administrative Code Title 22, Chapter 3, Articles 8 to 10) cover the design and operational considerations for alarms, power supply, emergency effluent storage and disposal, treatment processes, chemical supply, storage, and feed facilities. In general, operators may adopt different options to ensure the reliability of their process.

\section{Physical, Chemical, and Biological Characteristics of ReCLAIMED WASTEWATERS}

In the Western Hemisphere, municipal wastewater treatment has been practiced for over a century. Early attempts at reusing wastewater were plagued with pollution and public nuisances caused by hydraulic and pollutant overloading. Advances in treatment technologies enabled the production of treated wastewater effluents now suitable for a variety of uses. In this section, a brief description of the wastewater treatment processes and general principles of water purification and quality characteristics of source and finished waters will be reviewed in terms of water reuse potential.

\section{Wastewater Treatment Processes}

Municipal wastewater collection systems receive spent water and associated pollutants from discharges at service connections throughout a community. While the exact substances and their quantities are vague, all collected wastewaters contain impurities that may be categorized into the following general groups:

- biodegradable organic matter (BOM)

- pathogens and indicator organisms

- nutrients (nitrogen and phosphorus)

- potentially toxic substances

- dissolved minerals

To make the product water suitable for reuse or discharge, influent wastewater is routed through a series of unit processes through which impurities are removed. Treatment is divided into four general stages: preliminary, primary, secondary, and tertiary (or advanced). Depending on the desired characteristics of the target water and treatment objectives, unit processes can be selectively employed. Table 2 summarizes the goals and typical processes of each stage.

\section{Preliminary treatment}

Publicly owned treatment works (POTW) are designed and operated such that the processes in the preliminary stage prepare incoming wastewater for downstream treatment by measuring incoming flow and screening out oversized objects; separating sand, gravel, and other hard-to-handle objects (grit chamber); and equalizing the temporal and mass variations of the wastewater (flow measurement and equalization).

Table 2. Wastewater treatment processes: Purpose and example technologies

\begin{tabular}{|c|c|c|}
\hline Treatment stage & Purpose & Technologies \\
\hline preliminary & removal of large solids and grit particles & screening, settling \\
\hline primary & removal of suspended solids & screening, sedimentation \\
\hline secondary & $\begin{aligned} \text { biological treatment and removal of } \\
\text { common biodegradable organic pollutants } \\
\text { removal of specific pollutants, such as nitrogen } \\
\text { or phosphorous, color, odor, etc. }\end{aligned}$ & $\begin{array}{c}\text { percolating or trickling filter, activated sludge; anaerobic } \\
\text { treatment; waste stabilization ponds (oxidation ponds) }\end{array}$ \\
\hline tertiary (or advanced) & $\begin{array}{c}\text { sand filtration; membrane bioreactor; reverse osmosis; } \\
\text { ozone treatment; chemical coagulation; activated carbon }\end{array}$ \\
\hline
\end{tabular}




\section{Primary treatment}

The objective of primary treatment is to remove suspended solids from wastewater by gravity settling. The process continuously separates and withdraws solids as the water flows through a reactor with a hydraulic retention time ranging from 2 to 4 hours. Consequentially, contaminants associated with suspended solids are also removed. This process does not distinguish the chemical nature of the substances. Up to 50 to 70 percent of incoming suspended solids may be removed along with 25 to 50 percent of BOM and over 65 percent of the oil and grease. Domestic wastewater usually has a coliform bacteria count of greater than $10^{6}$ per $\mathrm{ml}$ of water. While up to 90 percent of the microorganisms may be eliminated, the amounts remaining in the treated water are still considerably large after the primary treatment.

\section{Secondary treatment}

The effluent from primary treatment is further processed to remove residual $\mathrm{BOM}$ and suspended solids through secondary (biological) treatment processes in which the biodegradable dissolved and colloidal organic matters are decomposed. The microbial biomass and water mixture in the reactor must undergo gravity settling to clarify the water. Part of the settled biomass may then be recycled to maintain the cell culture. After secondary treatment, more than 95 percent of the suspended solids, 90 percent of the BOM, and 99.99 percent of the microorganisms are expected to be removed. Frequently, the treated effluent is then disinfected by chlorination before releasing.

\section{Tertiary treatment}

Although secondary treatment is the minimum standard under the CWA for wastewater treatment, tertiary treatment is becoming more common. Tertiary treatment includes a collection of unit processes that are intended to remove residual contaminants that interfere with water reuse or harm aquatic ecosystem functions when the finished water is discharged. Tertiary treatment commonly targets nitrogen, phosphorus, residual suspended solids, refractory organics, and dissolved minerals that are not entirely removed during secondary treatment. Depending on the target pollutant, tertiary treatment may include one or more of the following methods.

\section{- Coagulation, flocculation, and filtration} remove residual suspended solids in the colloidal size range that do not readily settle by gravitation. The colloidal particles frequently shelter microorganisms harmful to humans and are sources of residual BOM, nitrogen, and phosphorus. Chemical coagulants such as lime, alum, ferric chloride, and electrolytes cause the colloidal particles to coalesce and transform into the suspended state to be trapped during filtration.

- Carbon adsorption removes trace organic substances that are the sources of color, odor, and foul taste in the water. They may taint fish flesh, cause foaming, and kill fish. The process has also been shown to reduce the levels of endocrine disruptors and metallic ions such as cadmium, silver, selenium, and hexavalent chromium. This process is essential for reclaimed wastewater to meet California's total organic carbon (TOC) rules in groundwater recharge.

- Nitrogen reduction is necessary for surface water discharge, in which ammonium nitrogen should be less than $1 \mathrm{mg} / \mathrm{l}$ to safeguard the aquatic organisms, and the total dissolved nitrogen should be maintained as low as possible. For land applications, the nitrogen level in reclaimed wastewater may not need to be reduced. Nitrogen, one of the limiting nutrients that feeds nuisance algae in receiving waters, is only partially removed with secondary treatment. Depending on the operating conditions, nitrogen in treated effluent may be in the form of ammonium nitrogen and/ or nitrate nitrogen. While processes have been specifically designed for nitrogen removal, the goal is frequently achieved by modifying the mass flow and operating conditions of the secondary treatment processes through which ammonia is oxidized into nitrate and then subsequently reduced to gaseous nitrogen.

- Phosphorus control is achieved through stepwise coagulation (flocculation) sedimentation processes that reduce the phosphorus concentration to less than $0.1 \mathrm{mg} / \mathrm{l}$. Phosphorus can also be removed along with nitrogen during biological nutrient removal processes, when the phosphorus concentration of the finished water is expected to be between 1.0 and $2.0 \mathrm{mg} / \mathrm{l}$. Like nitrogen, phosphorus is also an essential nutrient for algal blooms.

- Membrane filtration technology has been increasingly employed to obtain higher-quality water from wastewater and seawater. It is a separation process that excludes substances such as metal ions, viruses, bacteria, dissolved organic matter, and pesticides from the water stream, based on particle size, as the water being treated passes through the prescribed membranes under pressure. 


\section{Disinfection}

Even after rigorous treatment, treated wastewater may still contain disease-causing pathogens. To safeguard the public from exposure, pathogens and bacteria of sanitary importance must be eliminated before treated wastewater is released. Depending on the intended reuses, many states have established specific disinfection requirements and/or performance standards for treatment processes.

Chlorination is the most common and reliable disinfection method. The unspent residual chlorine provides long-lasting residual disinfection power, preventing the water from being recontaminated before its final release; however, unspent chlorine may also pose potential harm to plants if the reclaimed water is used for irrigation (see the section "Disinfection byproducts," below). Ozone and ultraviolet radiation are increasingly being used as alternative methods for disinfecting reclaimed wastewater and are especially effective for eliminating viruses and protozoan cysts in the water.

The effectiveness of disinfection is susceptible to suspended solids in water that tend to shelter target organisms from the power of disinfectants. The reactions triggered by the strong oxidants and radiation energy may also change the chemical nature of trace organic substances in water, resulting in the generation of unintended disinfection byproducts (DBPs). These disinfection byproducts are characterized as emerging trace compounds of concern; they are potentially toxic and may have adverse effects on the environment.

\section{Reclaimed Wastewater Quality Characteristics}

Starting from the source, impurities in water rise incrementally with each cycle of use, even with treatment. Municipal sewage is typically greater than 99.9\% water and less than $0.1 \%$ impurities of natural and anthropogenic origins. In addition to the chemical constituents, sewage also contains varieties of microbes, such as pathogens and bacteria, of sanitary importance. The composition of municipal wastewater is highly variable (table 3 ) due largely to the unpredictability of volumes and substances discharged at each service connection. Even for a single community, the composition of impurities in the wastewater may vary seasonally as well as diurnally.

While current wastewater reclamation technology is capable of producing finished water of any desirable

Table 3. Typical range of effluent quality after secondary treatment

\begin{tabular}{|c|c|c|c|c|c|c|c|}
\hline Constituent & $\begin{array}{c}\text { TSS } \\
(\mathrm{mg} / \mathrm{l})\end{array}$ & $\begin{array}{c}\text { BOD } \\
(\mathrm{mg} / \mathrm{l})\end{array}$ & $\begin{array}{l}\text { NH3-N } \\
(\mathrm{mg} / \mathrm{l})\end{array}$ & $\begin{array}{l}\text { Total N } \\
\text { (mg/l) }\end{array}$ & $\begin{array}{l}\text { Total P } \\
(\mathrm{mg} / \mathrm{l})\end{array}$ & $\begin{array}{l}\text { Turbidity } \\
\text { (NTU) }\end{array}$ & $\begin{array}{c}\text { Total coliform } \\
\text { per } 100 \mathrm{ml}\end{array}$ \\
\hline untreated wastewater & $120-400$ & $110-350$ & $12-45$ & $20-70$ & $4-12$ & 0 & $10^{6}-10^{9}$ \\
\hline conventional activated sludge & $5-25$ & $5-25$ & $1-10$ & $15-35$ & $4-10$ & $2-15$ & $10^{4}-10^{5}$ \\
\hline $\begin{array}{l}\text { conventional activated sludge } \\
+ \text { filtration }\end{array}$ & $2-8$ & $<5-20$ & $1-6$ & $15-35$ & $4-8$ & $0.5-4$ & $10^{3}-10^{5}$ \\
\hline activated sludge + BNR & $5-20$ & $5-15$ & $1-3$ & $3-8$ & $1-2$ & $2-8$ & $10^{4}-10^{5}$ \\
\hline $\begin{array}{l}\text { activated sludge }+ \text { BNR + } \\
\text { filtration }\end{array}$ & $1-4$ & $1-5$ & $1-2$ & $2-5$ & $\leq 2$ & $0.3-2$ & $10^{4}-10^{5}$ \\
\hline membrane bioreactor & $\leq 2$ & $<1-5$ & $<1-5$ & $<10^{*}$ & $<0.3^{\dagger}-5$ & $\leq 1$ & $<100$ \\
\hline $\begin{array}{l}\text { Activated sludge + microfil- } \\
\text { tration + reverse osmosis }\end{array}$ & $\leq 1$ & $\leq 1$ & $\leq 0.1$ & $\leq 1$ & $\leq 0.5$ & $0.01-1$ & $\sim 0$ \\
\hline
\end{tabular}

Key:

BNR = biological nutrient removal; BOD = biological oxygen demand; NTU = nephelometric turbidity units;

TSS $=$ total suspended solids.

Source: Adapted from Asano 2007.

Notes:

*With anoxic stage.

'With coagulant addition. 
quality, municipal wastewater that has undergone the previously described conventional treatments will experience quality changes due to differences in source and treatment processes. The amount of impurities in reclaimed wastewater may accentuate the potential impact on water reuse. Some impurities are of agronomic significance while others are of public health significance. A detailed discussion about these water quality problems is given in the following sections.

\section{Salinity}

As the salinity level of reclaimed wastewater increases, the growth of sensitive plants may also be reduced. Salinity is frequently expressed in terms of total dissolved solids (TDS) or electrical conductivity (EC, measured in $\mathrm{dS} / \mathrm{m}$ ) of the water, but plants respond primarily to TDS. An approximate relationship between EC and TDS can be described by (Tanji 1990):

$$
1 \mathrm{dS} / \mathrm{m} \approx 700 \mathrm{mg} / \mathrm{l}(\mathrm{TDS})
$$

The salinity level in reclaimed wastewater is invariably higher than that in the source water, making it less attractive aesthetically for certain types of reuse. Problems due to salinity, however, may be alleviated with proper irrigation management and selection of tolerant plant species. Models to help manage salinity in irrigated cropland are also available, such as WATSUIT (see the University of California Center for Water Resources Web site, http://lib.berkeley.edu/ WRCA/WRC/zip/Watsuit.zip).

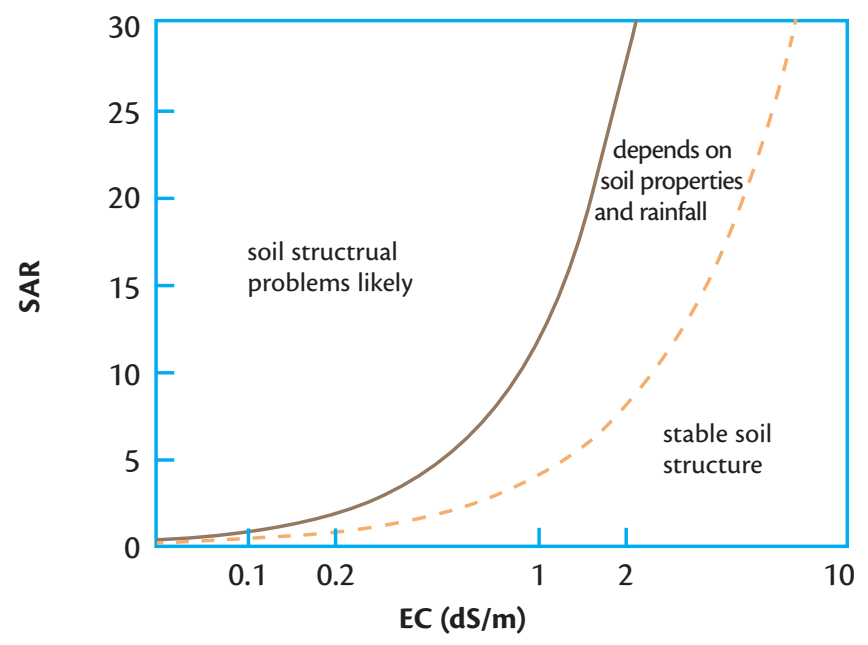

Figure 3. Relationship between sodium adsorption ratio (SAR) and electrical conductivity (EC) of irrigation water and likelihood of soil structure breakdown. Source: ANZECC and ARMCANZ 2000.

\section{Sodicity}

Changes in the mole fractions of $\mathrm{Na}+$ versus $\mathrm{Ca}++$ and $\mathrm{Mg}++$ on the cation exchange sites of soils may be assessed by exchangeable sodium percentage (ESP) or by the sodium adsorption ratio (SAR). The ESP of a soil is calculated from:

$$
\begin{aligned}
& E S P=[\text { exchangeable sodium }(\mathrm{meq} / 100 \mathrm{~g} \text { soil }) \div \\
& \text { cation exchange capacity }(\mathrm{meq} / 100 \mathrm{~g} \text { soil })] \times 100
\end{aligned}
$$

Since it is usually difficult to obtain reliable soil exchangeable cation data for calculating ESP, the SAR of soil solution, soil extract, or irrigation water is often used:

$\mathrm{SAR}=\mathrm{Na}+\div \sqrt{ }[(\mathrm{Ca}+++\mathrm{Mg}++) \div 2]$

where $\mathrm{Na}+, \mathrm{Ca}++$, and $\mathrm{Mg}++$ denote the concentrations of respective cations of the water (meq/l).

When the ESP exceeds 15\%, the higher level of $\mathrm{Na}+$ on the exchangeable sites may cause the soil aggregates to collapse due to dispersion, which leads to poor water penetration and greater soil compaction. While this phenomenon occurs naturally in many soils, the commencement of irrigation with reclaimed wastewater will most likely accelerate soil property deterioration as the reclaimed wastewater is proportionally higher in $\mathrm{Na}+$ than in $\mathrm{Ca}++$ and $\mathrm{Mg}++$.

In soils that contain very low to moderate amounts of exchangeable sodium (i.e., exchangeable sodium $<0.7 \mathrm{meq} / 100 \mathrm{~g}$ ) and have sufficiently low cation exchange capacities, the adverse effects on soil properties may be lessened considerably or altogether nonexistent. Soil sodicity is tied closely to the chemical properties of the irrigation water. Irrigation water that has a high ratio of $\mathrm{Na}+$ to $\mathrm{Ca}++$ plus $\mathrm{Mg}++$ and low salinity or contains calcium carbonate $(\mathrm{CaCO} 3)$ caused by the precipitation of calcium with bicarbonate (HCO3-) may induce high sodicity.

Likewise, a high SAR can cause poor soil infiltration. Generally, irrigation water with high SAR value (i.e., SAR > 9) can severely restrict permeability when applied to fine-textured clay soils over a period of time. But the sodic (SAR) effect of water is often evaluated together with salinity. At the same SAR level, soil is more susceptible to dispersion in low-salinity water than in high-salinity water (fig. 3). In coarse-textured (sandy) soils, restrictions on permeability are less severe, and the water with this magnitude of SAR may be tolerated. 
For details about salinity and sodicity, see Saline and Alkaline Soils (USDA Handbook 60, Richards 1954); on proper management of irrigated lands, see Water Quality for Agriculture (Ayers and Richards 1985).

\section{Potentially toxic elements: Boron, chloride, sodium, and heavy metals}

High levels of boron, chloride, and sodium in irrigation water are potentially harmful to plants. Heavy metal elements may accumulate in the receiving soils and harm plant growth or be transferred through the food chain to adversely affect consumers of the harvests.

Boron is by far the most likely element to harm plants irrigated with reclaimed wastewater. Small amounts of boron (i.e., $<0.5 \mathrm{mg} / \mathrm{kg}$ ) are essential for plant growth, but at only slightly higher concentrations $(>0.5 \mathrm{mg} / \mathrm{l}$ in irrigation water), it may become toxic to plants. Plant tolerance to boron in soils varies widely. The threshold is established based on boron concentrations in soil saturation extracts; it may be as low as 0.5 $\mathrm{mg} / \mathrm{l}$ for sensitive plants or greater than $16 \mathrm{mg} / \mathrm{l}$ for tolerant plants. (For more information about boron plant toxicity, see Rhoades et al. 1992.) Concentrations of boron in reclaimed wastewater principally originate from household detergents and cleansing agents and are not expected to be high enough to cause immediate harm to plants. However, boron may accumulate in the root zone through long-term use of reclaimed wastewater.

Chloride and sodium ions are major dissolved constituents of wastewater. In addition to their role in salinity, both chloride and sodium may be harmful to plants at high concentration (see Rhoades et al. 1992).

While trace elements such as arsenic (As), copper $(\mathrm{Cu})$, chromium $(\mathrm{Cr})$, molybdenum $(\mathrm{Mo})$, nickel $(\mathrm{Ni})$, selenium (Se), and zinc ( $\mathrm{Zn}$ ) are found in municipal wastewater, conventional wastewater treatment processes effectively remove them from the water stream, and they concentrate in the sludge fraction. As a result, their presence in reclaimed wastewater is largely negligible and the concentrations are comparable to the levels found in fresh water. Based on past experiences in land application of reclaimed wastewater, trace elements do not constitute a problem in soil accumulation or through food chain transfer (see Asano 2007; O'Connor et al. 2008), but their fate and transport to groundwater remain largely unknown.

\section{Nutrients}

Reclaimed water can serve as a source of nutrients essential for plant growth, such as nitrogen, phosphorus, and potassium. These nutrients are beneficial to plants, but if not properly managed, they may cause many problems, such as nutrient imbalances, eutrophication of surface waters, and contamination of groundwater. Among them, nitrogen is the most noteworthy because significant amounts of nitrogen may be applied in a reclaimed wastewater irrigation operation. It is imperative that fertilization practices be adjusted to account for the added inputs from wastewater to avoid overapplication that may result in adverse impacts on water quality.

\section{Chlorine residues}

Chlorine residues are inherent to reclaimed wastewater; they gradually dissipate while the finished water is in storage. Excessive amounts of available free chlorine may cause leaf-tip burn and may damage sensitive crops if still present at the time of application. For turfgrass where water applications are frequent, the grass may become discolored over time and exhibit a slight yellow tinge. No scientifically based threshold values for plant injury are available, but a chlorine level less than $5 \mathrm{mg} / \mathrm{l}$ is considered to be safe.

\section{Disinfection byproducts}

When reclaimed wastewater is disinfected, the chemical oxidation process also produces disinfection byproducts (DBPs) that are primarily dissolved organohalogens derived from the oxidative breakdown of dissolved low-molecular-weight organic substances in water. Chlorination, the most commonly used disinfection process, produces more byproducts with relatively high concentrations than do other methods of disinfection. When reclaimed wastewater is chlorinated, it requires a high chlorine dosage and long contact time, conditions especially conducive to the formation of byproducts.

In chlorinated wastewater effluents, there may be hundreds of disinfection byproducts, of which only a small fraction has been identified. In general, byproducts may be grouped into the following: trihalomethanes, haloacetonitriles, haloketones, haloacetic acids, chlorophenols, aldehydes, trichloronitromethane, chloral hydrate, and cyanogen chloride. Among them, trihalomethanes and haloacetic acids are by far the most common and are often present at higher concentrations than the others, which are less frequently found. Under the most conducive condition for byproduct production (fully nitrified secondary effluents), the total chlorine levels in chlorinated reclaimed wastewater were found to be as high as $3,000 \mu \mathrm{g} / \mathrm{l}$.

Long-term exposure to disinfection byproducts may cause cancers (Cantor et al. 1998; Hildesheim et al. 1998) or result in spontaneous abortion in the early trimesters of pregnancy (Swan et al. 1992). The 
likelihood of harm caused by disinfection byproducts is derived primarily from direct ingestion of chlorinated water. In crop irrigation, consumers may be indirectly exposed to them through food chain transfer or contamination of the underlying groundwater. Disinfection byproducts are, however, subject to volatilization in the ambient environment and are readily degraded through chemical and biological reactions. Because chlorinated reclaimed wastewater is typically stored until the time of irrigation, byproducts formed during disinfection are expected to decay during storage. After land application, those that remain after storage will continue to degrade in the soil and are not expected to accumulate.

It is also unlikely that disinfection byproducts pose a serious threat to groundwater underneath irrigated fields. Unless nonvolatile and refractory compounds are found in chlorinated reclaimed water, disinfection byproducts are not likely to be a limiting factor in reclaimed wastewater irrigation. However, one must be aware of their potential environmental harm and reassess the merit of reclaimed water irrigation if new information on their environmental fate becomes available.

\section{Pathogens}

The greatest health concern in using reclaimed wastewater for irrigation is directed to pathogens. Pathogens are inactivated through proper treatment and disinfection of wastewater. Reclaimed wastewater has been used for irrigation for many decades and thus far no scientific investigation has found that reclaimed wastewater irrigation has contributed to human illness. The potential for disease transmission through reclaimed water reuse, however, has not been completely eliminated. Thus, proper management is necessary to prevent disease transmission to humans by bacteria, parasites and viruses in reclaimed water (for more information, see Westcot 1997).

Epidemiological data is not available that shows any relationship between the quality of water actually applied at the field level and disease transmission or infection. The U.S. Environmental Protection Agency's guideline gives the maximum acceptable level for irrigation with natural surface water, including river water, as $800 \mathrm{fecal}$ coliforms per $100 \mathrm{ml}$ (EPA 2004). The World Health Organization's (2006) recommendation for wastewater use in agriculture is given in table 4 . All the pathogens have the potential to reach the field, but many factors, including crop type, irrigation method, cultural and harvesting practices, and environmental conditions (e.g., temperature and humidity) can affect transmission of disease. Proper agronomic management can reduce and minimize the potential for disease transmission.

\section{Pharmaceutically active chemicals and endocrine disruptors}

Residues of over-the-counter and prescription drugs including antiphlogistics (such as ibuprofen and naproxen), lipid regulators, and beta-blockers have been found in treated wastewater effluents

Table 4. Recommended microbiological quality guidelines for wastewater use in agriculture

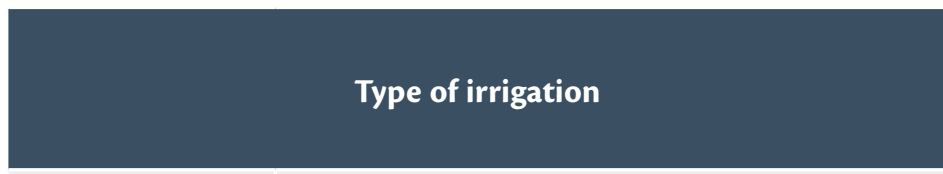

Required pathogen reduction by treatment ( $\log$ units)
Verification monitoring level

(E. coli per $100 \mathrm{ml}$ )

\begin{tabular}{|c|c|c|c|}
\hline \multirow{5}{*}{ unrestricted } & root crops & 4 & $\leq 10^{3}$ \\
\hline & leaf crops & 3 & $\leq 10^{4}$ \\
\hline & drip irrigation of high-growing crops & 2 & $\leq 10^{5}$ \\
\hline & drip irrigation of low-growing crops & 4 & $\leq 10^{3}$ \\
\hline & $\begin{array}{l}\text { verification level depends on the } \\
\text { requirements of the local regulatory agency }\end{array}$ & 6 or 7 & $\leq 10^{1}$ or $10^{\circ}$ \\
\hline \multirow{3}{*}{ restricted } & labor-intensive agriculture & 3 & $\leq 10^{4}$ \\
\hline & highly mechanized agriculture & 2 & $\leq 10^{5}$ \\
\hline & pathogen removal in a septic tank & 0.5 & $\leq 10^{6}$ \\
\hline
\end{tabular}

Source: WHO 2006. 
(Xu et al. 2008). Among the pharmaceutically active ingredients, the residues of antibiotics and hormonelike compounds have attracted the most attention. Although conventional wastewater treatment is not designed specifically to remove these potentially harmful chemicals, the treatment processes nevertheless effectively reduce their concentrations in the treated effluents, usually to less than $10 \mu \mathrm{g} / \mathrm{l}$.

In treated wastewater effluents, concentrations of drug and non-drug-related estrogenic chemicals have been reported in the ranges of 1 to $100 \times 10^{-9} \mathrm{~g} / \mathrm{l}$ and 0.1 to $30 \times 10^{-6} \mathrm{~g} / \mathrm{l}$, respectively (Arcand-Hoy and Benson 1998). When the effluent is used for irrigation, the hormones increase the endogenous production of phytohormones in legumes like alfalfa. These phytohormones can then cause fertility problems in sheep and cattle that consume the forage (Tyler et al. 1998).

Some substances, though not hormones themselves, can disrupt the hormonal (endocrine) system in humans and other mammals (most notably aquatic organisms such as fish and amphibians). These endocrine disruptors (EDCs) are primarily synthetic chemicals that interact with endocrine systems and result in the disruption of normal biological functions, such as growth, development, and maturation. When interacting with the endocrine system of an organism, these substances may act like a natural hormone and bind to a receptor, interfere with the normal hormonal responses by binding and therefore blocking the receptor, or interfere with the organism's synthesis and control of natural hormones. Some substances exhibiting endocrine-disrupting properties include organochlorine pesticides (e.g., DDT, dieldrin, lindane, atrazine, trifluralin, and permethrin), surfactants (e.g., alkylphenols and their degradation products nonylphenol and octylphenols), plasticizers (e.g., dibutyl phthalate, butylbenzylphthalate, diethylhexylphthalate, and polyethylphthalate), PCBs, dioxins, and tributyltin. When exposed to high concentrations, adverse effects of select chemicals on the development and reproduction, cognitive and neurobehavior, and immunoresponses of exposed organisms have been demonstrated (National Research Council 1999).

There is inadequate technical information to assess the potential adverse impacts of endocrinedisrupting chemicals released during landscape application or agricultural irrigation of reclaimed wastewater. When they are present in the soil, certain linear alkylsulfanate surfactants (LAS) and their degradation byproducts (nonylphenols) are subject to rapid microbial degradation. They are also expected to be adsorbed to the soil organic matter. As a result, they are not likely to enter the plant tissue through root absorption. However, if wastewater is released to natural water bodies, the potential ecotoxicological consequences cannot be overlooked.

\section{Other water quality indicators}

The following brief description of water quality indicators does not indicate these indicators are not as important as water quality parameters. These indicators are less specific to reclaimed wastewater, and information about them is widely available.

- $\mathbf{p H}$. One of the most important parameters that affects metal solubility as well as alkalinity of soils.

- Biodegradable organics. Measured by BOD, COD, or TOC. Biodegradable organics cause aesthetic and nuisance problems, adversely affect disinfection processes, and deplete soil oxygen.

- Stable (refractory) organics. Organic compounds such as phenols, pesticides, and chlorinated hydrocarbons are resistant to degradation in conventional methods of wastewater treatment. Some are toxic in the environment and may accumulate in the soil.

\section{Reclaimed Wastewater Applications FOR AGRICULTURE AND LANDSCAPE}

Reclaimed wastewater is most commonly used for irrigation and environmental enhancements that include landscape and turf irrigation, decorative fountains and landscape impoundments, and crop irrigation. With proper treatment of water and proper field management, reclaimed water can be used safely in these settings. The degradation in soil properties and potential for plant injuries associated with the incremental increases in salinity and harmful elements are also manageable issues.

\section{Safe Use of Reclaimed Wastewater}

When reclaimed wastewater is used for agriculture and landscape irrigation, certain measures must be taken to ensure safe use.

\section{Setback distances}

The setback distances, or buffer zones, between reuse sites and other facilities such as potable water supply wells, property lines, residential areas, and roadways are added safeguards. The actual distances depend on the quality of the reclaimed water and the method of application. For example, Nevada's regulations require a buffer of 400 to 800 feet, depending on disinfection level, for a spray irrigation system, while no buffer is 
required for surface application of reclaimed wastewater (see Nevada Administrative Code, Chapter 445A). Table 5 summarizes the guidelines suggested by the EPA (2004) regarding water quality monitoring and appropriate setback distances.

\section{Cross-connection control}

Cross-connections between reclaimed water and potable water delivery systems should not exist, and all possible measures must be exercised to prevent such cross-connections from occurring. Generally, prevention provisions are stipulated in the plumbing codes and are achieved through installation and regular testing of backflow prevention and air gap separation devices. The cross-connection prevention plan of a water reuse project is subject to the review and approval of the permitting agencies and reclaimed water purveyors prior to the installation.

\section{Salinity management}

When leaching is not required, the water needed for normal plant growth is equal to evapotranspiration
(ET). However, additional water is often required for leaching in order to keep salinity in check. This leaching requirement (LR) depends on the salinity of irrigation water $(\mathrm{ECw}, \mathrm{dS} / \mathrm{m})$ and the crop tolerance to soil salinity (ECe, dS/m), which can be estimated based on the following equation:

$$
L R=E C w \div(5 \times E C e-E C w)
$$

Therefore, the total amount of applied water (AW) to meet both the crop demand and leaching requirement can be estimated by

$$
A W=E T \div(1-L R)
$$

\section{Application rates and times}

How much water to apply and when to apply it are often a part of the water reuse plan. The maximum application rate is governed by the hydraulic loading capacity of the receiving soils. When reclaimed water is used in groundwater recharge, there is a tendency

\begin{tabular}{|c|c|c|}
\hline Use category & Monitoring requirement & Setback distance \\
\hline $\begin{array}{l}\text { urban reuse or agricultural reuse: } \\
\text { food crops not commercially processed }\end{array}$ & $\begin{array}{c}\text { weekly: } \mathrm{pH} \text { and } \mathrm{BOD} \\
\text { daily: coliform } \\
\text { continuous: turbidity, } \mathrm{Cl} 2 \text { residue }\end{array}$ & $15 \mathrm{~m}$ to potable water supply wells \\
\hline $\begin{array}{l}\text { restricted access area or agricultural reuse: } \\
\text { food crops commercially processed; } \\
\text { agricultural reuse: nonfood crops }\end{array}$ & $\begin{array}{l}\text { weekly: } \mathrm{pH} \text { and } \mathrm{BOD} \\
\text { daily: } \mathrm{TSS}, \text { coliform } \\
\text { continuous: } \mathrm{Cl} 2 \text { residue }\end{array}$ & $\begin{array}{l}90 \mathrm{~m} \text { to potable water supply wells; } \\
30 \mathrm{~m} \text { to areas accessible to the public, } \\
\text { if spray irrigated }\end{array}$ \\
\hline recreational impoundments & $\begin{array}{c}\text { weekly: } \mathrm{pH} \text { and } \mathrm{BOD} \\
\text { daily: coliform } \\
\text { continuous: turbidity, } \mathrm{Cl} 2 \text { residue }\end{array}$ & $\begin{array}{l}150 \mathrm{~m} \text { to potable water supply well, } \\
\text { if bottom not sealed }\end{array}$ \\
\hline landscape impoundments & $\begin{array}{c}\text { weekly: } \mathrm{pH} \\
\text { daily: } \mathrm{TSS}, \text { coliform } \\
\text { continuous: } \mathrm{Cl} 2 \text { residue }\end{array}$ & $\begin{array}{l}150 \mathrm{~m} \text { to potable water supply wells, } \\
\text { if bottom not sealed }\end{array}$ \\
\hline industrial reuse: cooling water & $\begin{array}{l}\text { weekly: } \mathrm{pH} \text { and } \mathrm{BOD} \\
\text { daily: TSS, coliform } \\
\text { continuous: } \mathrm{Cl} 2 \text { residue }\end{array}$ & $90 \mathrm{~m}$ to areas accessible to the public \\
\hline $\begin{array}{l}\text { environmental reuse } \\
\text { (wetlands, steam augmentation) }\end{array}$ & $\begin{array}{c}\text { weekly: } \mathrm{BOD} \\
\text { daily: } \mathrm{TSS}, \text { coliform } \\
\text { continuous: } \mathrm{Cl} 2 \text { residue }\end{array}$ & not applicable \\
\hline groundwater recharge & depends on treatment and use & Site-specific \\
\hline
\end{tabular}

Table 5. EPA guidelines (2004) on water quality monitoring and setback distances 
to push the application rate to the maximum. When reclaimed water is used for irrigation, the hydraulic loading rates are more likely dictated by the plant requirements in terms of evapotranspiration, nutrient intake, and salinity tolerance; therefore, the rates are generally site-specific in accordance with best management practices. The timing of reclaimed water applications may be scheduled to minimize potential direct human contact with any spray or aerosols. For example, the Irvine (California) Ranch Water District requires that the public parks, golf courses, and public and private landscaping receiving reclaimed water must irrigate during the off-hours between 9:00 pm and 6:00 am (IRWD 2002).

\section{Water Quality Issues}

Recycled water is wastewater treated to a quality high enough to be safe and effective for approved uses such as landscape irrigation. It is clear, odorless, and free of harmful bacteria. However, it typically does contain more salts and nutrients than those found in potable water. Some of these constituents can be beneficial to landscapes, while others may be harmful. For example, nitrogen, calcium, and magnesium can help to enrich a soil and reduce the need for commercial fertilizers. On the other hand, excessive concentrations of sodium, chloride, and boron can harm plant and soil health (see the section "Physical, Chemical, and Biological Characteristics of Reclaimed Wastewaters," above, for more details). Although the chemical properties of recycled water depend on the treatment facility, generally the only compound remaining after treatment that is potentially harmful to landscape plants is sodium chloride. Other elements such as boron, selenium, magnesium, and cadmium are rarely found to be above safety levels. Since most landscape plantings are not monocultures (one crop) as they are in agriculture, salt concentrations in recycled water must be acceptable for wide ranges of landscape plant species.

\section{Landscape Irrigation Using Reclaimed Wastewater}

\section{Distribution of reclaimed wastewater}

In the arid southwest, a significant proportion of urban water use is for outdoor landscape maintenance. The potential for using reclaimed wastewater in landscape irrigation is realistic where a conveying system exists to distribute the water. While a limited number of communities in the United States have dual and separate water distribution systems for potable and nonpotable water, most water reuse projects must include capital investment on infrastructure to distribute the reclaimed wastewater. The nonpotable supply may be used for landscape irrigation and toilet flushing (especially in high-volume commercial and business facilities), while the potable supply provides water for drinking, food preparation, and other indoor household uses. Unless reclaimed wastewater is readily accessible in the community, the lack of an established distribution network will restrict the extent of the reuses. No single factor is likely to influence the cost of water reclamation more than the conveyance or distribution of reclaimed water from its source to its point of use.

A distribution network includes pipelines, pump stations, and storage facilities. The design of distribution facilities is based on topographical conditions as well as reclaimed water demands. If the topography has wide variations, multilevel systems may have to be used. Figure 4 provides a schematic of the various reuse conveyance and distribution systems that may be encountered. During the design, the most important considerations are the reliability of service and protection of public health. The following safeguards must be considered during the design of an urban reclaimed water distribution system.

- The recycled water agency must assure that the reclaimed water delivered to the customer meets the water quality standards for the intended uses.

- Variations in the demand for reclaimed water occur seasonally. Large volumes of seasonal storage may be needed if all available reclaimed water is to be used, although this may not be economically practical. The selected location of a seasonal storage facility will also have an effect on the design of the distribution system.

- To prevent the misuse of reclaimed water, piping, valves, and hydrants should be marked or colorcoded (e.g., purple pipe) to differentiate reclaimed water from potable water.

- Where a dual distribution system is created, the design will be similar to that of a potable system in terms of pressure and volume requirements. However, if the reclaimed water distribution system does not provide for an essential service such as fire protection or sanitary uses, the reliability of the reclamation system need not be as stringent.

- There should be no cross-connection between potable and reclaimed water lines. The American Water Works Association recommends that effluent distribution lines be buried at least 1 foot deeper 
than the domestic water lines and be operated at a lower pressure differential (AWWA 1994).

- If potable water is to be used as a backup source to the recycled water system, the potable water should be separated by an air gap separation mechanism approved by the appropriate regulatory agencies (for example, the state Department of Health Services and the local city or county health department). A reduced-pressure-principle backflow prevention device or a double check valve should also be installed at the potable water service connection.

- If the service pressure is higher than the user can accept, the user is generally responsible for providing a pressure reducing valve downstream of the service meter. If the service pressure is lower than what the user needs, the user is responsible for providing booster pumping downstream of the meter. Any pumping of recycled water requires the prior written approval of the recycled water agency.

\section{Management practices}

In addition to water quality, many other important factors must be considered when irrigating landscape plants with recycled water. Some of these include the frequency of irrigation, quantity of water applied, method of application, and water-holding capacity of the soil. Proper site management, and specifically, proper water management, is the key to successful landscaping with recycled water.

The basic principles of managing irrigated landscaping do not distinguish whether the source water is a reclaimed wastewater or a potable source. These principles require managers to have full knowledge of the quality of the applied water and to adjust the practices according to the salinity, nutrient

\section{Special Needs Customers}

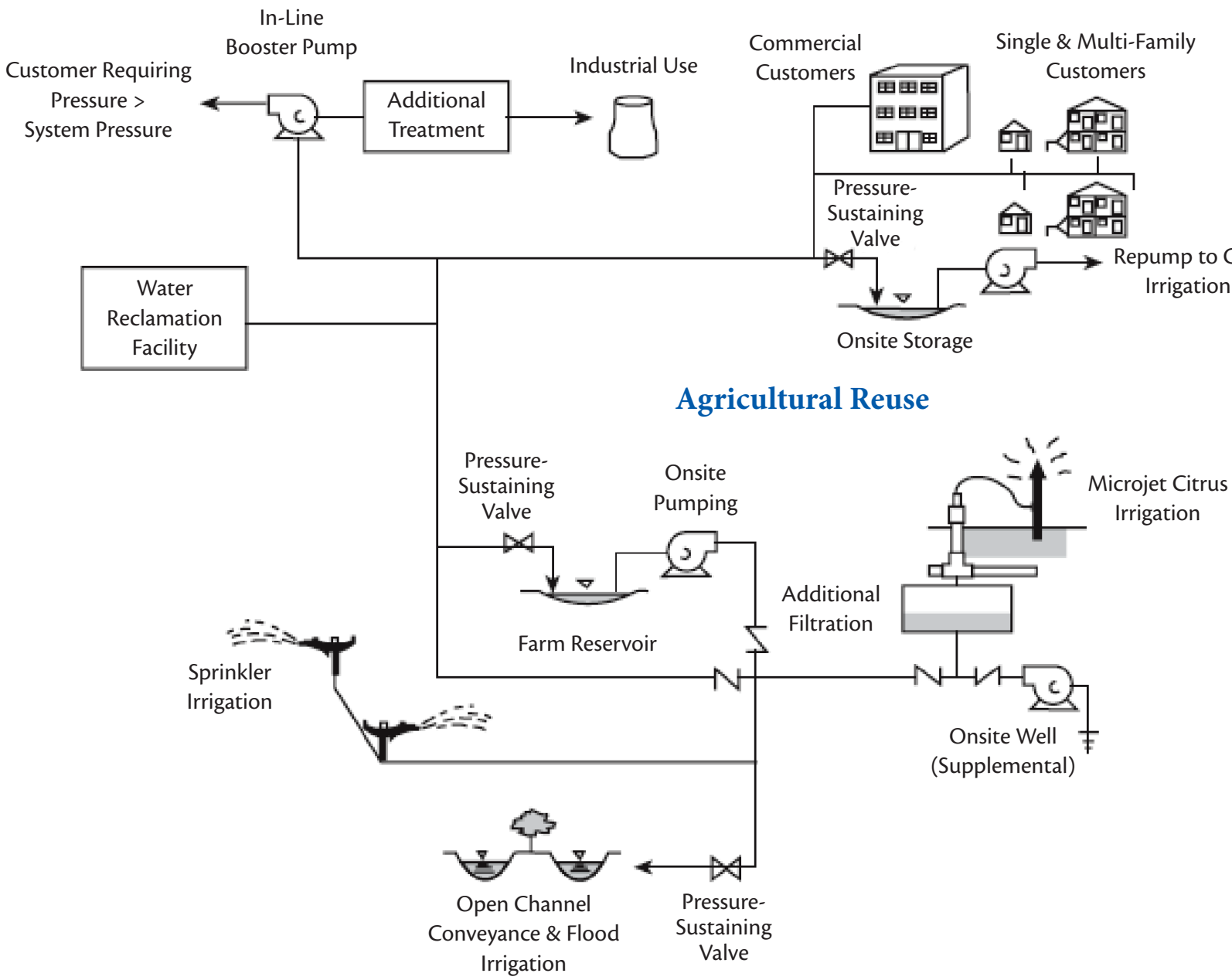

Figure 4. A multiple reuse distribution system. Source: EPA 2004. 
contents, and toxic chemical contents of the water. The following elements should be factored in to the field water management scheme.

- Inclusion of appropriate methods and equipment for water application to improve the control of irrigation efficiency and soil salinity and to minimize public health risks. For example, some plant species that show a sensitivity to direct leaf contact with spray irrigation show no sensitivity when irrigated with soil-applied or drip irrigation. In any event, infrequent, heavy irrigation should be applied rather than frequent, light irrigation. This allows the leaf surface and the soil to dry out between irrigations, minimizing or eliminating salt stress damage. Improving drainage by means of cultivation, adding organic matter to the soil, and adding gypsum also greatly aid in limiting any damage from salt buildup in the root zone.
- Consideration of plant tolerance to salinity and boron in landscaping designs.

- Employing chemical amendments (i.e., gypsum, lime, sulfur, and organic matter) to modulate nutrient availability, SAR, and $\mathrm{pH}$ of receiving soils.

- Using buffer zones where low-quality (secondary and lower) reclaimed water is used.

- Blending reclaimed water with water sources that have a lower SAR or lower TDS, if necessary and feasible, through seasonal use of alternate sources of water or real-time blending with such water.

- Balancing fertilization with the amount of fertilizer present in reclaimed water.

- Providing an adequate leaching fraction and good drainage, especially on golf course greens and other intensely played surfaces.
Table 6. Effluent quality (in $\mathrm{mg} / \mathrm{l}$, except as specified) of Michelson Water Reclamation Plant

\begin{tabular}{|c|c|c|c|}
\hline Parameter & Range & Average & Limit \\
\hline biochemical oxygen demand & ND-11 & ND & 20 \\
\hline chemical oxygen demand & $12-41$ & 23 & NA \\
\hline chlorine residual & $3.2-17.1$ & 10.0 & NA \\
\hline electrical conductivity ( $\mu \mathrm{mhos} / \mathrm{cm})$ & $538-1265$ & 892 & NA \\
\hline $\mathrm{pH}(-)$ & $6.5-6.8$ & 6.6 & $6.5-8.5$ \\
\hline total dissolved solids & $566-812$ & 680 & 720 \\
\hline suspended solids & ND-4.5 & 1.3 & 20 \\
\hline turbidity (NTU) & $0.4-2.0$ & 1.0 & 2.0 \\
\hline coliform bacteria (MPN/100ml) & ND-23 & ND & 2.2 \\
\hline arsenic & ND-0.0029 & 0.0016 & 0.05 \\
\hline boron & $0.28-0.59$ & 0.5 & 1 \\
\hline cadmium & ND-0.0002 & ND & 0.01 \\
\hline chloride & $102-183$ & 137 & 150 \\
\hline chromium & $0.0007-0.0041$ & 0.0017 & 0.05 \\
\hline cobalt & $0.0003-0.0007$ & 0.0005 & 0.2 \\
\hline copper & $0.0032-0.0083$ & 0.0060 & 0.02 \\
\hline fluoride & $0.28-0.55$ & 0.45 & 1.0 \\
\hline lead & $0.0016-0.0050$ & 0.0033 & 0.05 \\
\hline mercury & ND-0.0007 & ND & 0.002 \\
\hline nitrate (as N) & $2.9-5.5$ & 4.5 & NA \\
\hline total $\mathrm{N}$ & $6.9-13.0$ & 8.57 & NA \\
\hline phosphate, ortho (as P) & $0.2-2.9$ & 1.2 & NA \\
\hline potassium & $14.3-37.3$ & 20 & NA \\
\hline sodium & $116-142$ & 129 & 125 \\
\hline zinc & $0.0388-0.0867$ & 0.0666 & 0.1 \\
\hline
\end{tabular}

Key: $\mathrm{NA}=$ not analyzed; ND = not detected; NTU = nephelometric turbidity units. Source: IRWD 2006.
For details, readers are referred to the management practices outlined in Water Quality for Agriculture (Ayers and Westcot 1985).

\section{Case study: William R. Mason Regional Park, Irvine, CA}

The first phase of Mason Park opened to public use in 1973 with 45 acres; a 50 -acre second phase, including a 9.2-acre lake, was completed in 1978. The artificial lake in the center of the park is a popular attraction for visitors as well as for migrating birds and other local wildlife. Treated wastewater (tertiary or advanced treatment) from Irvine Ranch Water District's Michelson Water Reclamation Plant (MWRP) is used at the park for irrigation and for filling the lake. The reclaimed water produced at MWRP carries an unrestricted use permit from the California Department of Public Health. This water meets the stringent requirements of Title 22 of the state Health Code and is of such high quality that it can be used for everything but drinking. Water quality constituents within detectable limits are given in table 6 .

Based on the characteristics of the reclaimed water, irrigation scheduling and practices for the park were developed to minimize potential adverse impacts on people as well as on the environment. Proper management of 
irrigation with reclaimed water has enabled the park to provide a recreational and scenic resource to the community without using potable water supplies. These management practices include the following.

- By recognizing that reclaimed water usually contains high salt concentrations, additional water should be applied as a "leaching requirement" to wash out the excessive salt accumulation.

- Reclaimed water contains certain amount of nutrients; therefore, lawn fertilization should account for the amount of nutrients in the reclaimed water.

- Long intervals should be used between irrigation events to stimulate deep root growth and facilitate ground maintenance and public enjoyment.

- During irrigation events, short and frequent water application should be used to reduce surface runoff. For example, if the total irrigation run time is 15 minutes, this period is divided into 3 running times of 5 minutes on separated by 5 to 10 minutes off.

- The landscape should be irrigated between $10 \mathrm{pm}$ and 7 am to minimize the public's direct exposure to reclaimed water.

- Plant species should be selected that are more tolerant to salinity. Adjustments were made after several tree species did not grow well using reclaimed water, mainly because of the relatively high salinity level.

- Reclaimed water should be prevented from making contact with wood structures. Plastic materials and galvanized steel rather than wood should be used to avoid the relatively fast decay of wood materials, and they should be painted more frequently to reduce rust and decay.

- Lavatories and drinking fountains should be bleached to reduce the potential for human exposure to pathogens. Drinking fountains near turf areas may come in contact with the reclaimed water through spray from sprinklers.

- No diving or swimming is allowed.

\section{Reclaimed Wastewater Applications in Agriculture}

Success in using reclaimed wastewater for crop production largely depends on adopting appropriate strategies to optimize crop yield and quality, maintain soil productivity, and safeguard the environment. In general, application of reclaimed wastewater for agriculture follows the same principles as for landscape irrigation as discussed in the previous section. Therefore, the following sections focus primarily on management practices specific to agricultural irrigation using reclaimed wastewater.

\section{Management practices}

Irrigation run time. Many irrigation systems are designed to apply water for short periods of time, perhaps many nights a week. Compared to longer irrigation run times done on a less frequent basis, short irrigation runs can deposit more salt in the root zone, with possible adverse impacts on plant health and growth. Heavier watering done less frequently leaches the accumulating salts out of the root zone.

Amount of water applied. In addition to the irrigation run time, the amount of water applied is also an important factor to prevent accumulation of salts in the soil. Insufficient irrigation leads to a decrease in crop production due to salinity accumulation in the crop root zone. However, excessive flooding can inhibit aeration, leach nutrients, induce secondary salinization, and pollute groundwater. Irrigation requirements depend on the crop, the stage of plant growth, and climatic conditions. A computer program, CROPWAT, can be downloaded from the FAO website to determine the water requirements of various crops from climatic data from almost all continents (http:// www.fao.org/ag/AGL/aglw/cropwat.stm).

Irrigation method. Reclaimed wastewater may be applied by all modes of irrigation, depending on the specific situation. From a health aspect, drip irrigation systems provide the best protection as they are totally closed systems and avoid the problems of worker safety and drift control. However, drip irrigation requires strict maintenance for proper operation. Clogging problems are likely to occur, particularly with effluents from primary sedimentation and oxidation ponds. The suitability of a given water source for use in drip irrigation systems can be evaluated based on the guidelines proposed by Hanson et al. 1997 (table 7). In addition to health considerations, the financial cost as well as salinity buildup and toxicity hazards associated with different irrigation methods should be also taken into account.

Fertilizer adjustment. Growers should take into account the value of nutrients in reclaimed water and reduce consumption of fertilizers accordingly. They should also keep in mind the risk of oversupplying nitrogen when irrigating with recycled water. For 
example, if the reclaimed water contains an average total nitrogen of $10 \mathrm{mg} / \mathrm{l}\left(\right.$ or $\left.10 \mathrm{~g} / \mathrm{m}^{3}\right)$, the total nitrogen input from 1 acre-foot of the water will be

$$
\begin{aligned}
& 10 \mathrm{~g} / \mathrm{m}^{3} \times 1 \mathrm{AF} \times 1,233 \mathrm{~m}^{3} / \mathrm{AF}=12330 \mathrm{~g} / \mathrm{AF}, \\
& \text { or } 27.2 \mathrm{lb} / \mathrm{AF}
\end{aligned}
$$

Excess nitrogen (over $30 \mathrm{mg} \mathrm{N}_{\text {tot }} / \mathrm{l}$ ) can reduce crop quality and may exacerbate deficiencies of other nutrients, such as phosphorus or potassium, if these are not provided in appropriate ratios. To optimize crop yield and quality, additional fertilizers may be supplied during specific crop growth stages. If the reclaimed wastewater is high in nitrogen content, it is desirable to choose plant species with a high nitrogen demand to reduce the possibility of deep nitrogen percolation and groundwater pollution.

Air quality considerations. Although no data are available to quantify the amount of the nitrogen volatilization, sprinkler irrigation of reclaimed wastewater may release some of the ammonia to the air, which may contribute to the formation of PM 10 (see EPA 2008).

\section{Case study: City of Bakersfield Reclaimed Wastewater Application Field}

Adjacent to the city of Bakersfield, California, is a municipal farm of greater than 2,000 hectares that has been continuously cultivated and irrigated with an annual average of 0.8 to 1.2 meters (depending on the crop rotation) of reclaimed municipal wastewater for over 80 years. The reclaimed water is stored in reservoirs and used to fulfill seasonal demands of irrigation for greenchop winter grain forage (Hordeum and Triticum spp.), corn grain and silage (Zea mays), wheat (Triticum sativum), cotton (Gossypium hirsutum), alfalfa (Medicago sativa), and sorghum (Sorghum vulgare). During this 80-year period, the wastewater collection and treatment system has continuously evolved in response to both the growth of the city and regulatory requirements. As inflows and outflows of the reservoirs fluctuated dynamically with supply and demand, no record was kept of the chemical characteristics of the applied water. However, recent measurements indicate that the electric conductivity of the effluent from the treatment plant is about 0.7 to $0.9 \mathrm{dS} / \mathrm{m}$, with an SAR of about 3.

A second field, considered as a control field with the identical soil series and elevation aspect, is located one-half mile west of the treated field. For approximately an equal length of time, this field has been cultivated with similar crops using very low-salinity Kern River water supplied by the Kern Delta Water District.

Soils in these two fields were sampled in September 1998, at the end of the growing season (Wang et al. 2003). One hundred soil samples were taken at 1-meter intervals along a 100-meter transect perpendicular to the direction of irrigation furrows and approximately 150 meters down field from the heads of the furrows. For this study, 29 physical, chemical, and biological attributes of the soils at the treated field and its adjacent nontreated control field were determined. Except for the total porosity and magnesium, the soil parameters of the control and treated fields were not significantly different. While the soils of both fields support successful crop production,

Table 7. Water quality and clogging potential in drip irrigation systems

\begin{tabular}{|c|c|c|c|c|}
\hline & \multicolumn{3}{|c|}{ Degree of restriction on use } \\
\hline Potential problem & Units & None & Slight to moderate & Severe \\
\hline suspended solids & $\mathrm{mg} / \mathrm{L}$ & $<50$ & $50-100$ & $>100$ \\
\hline $\mathrm{pH}$ & - & $<7.0$ & $7.0-8.0$ & $>8.0$ \\
\hline dissolved solids & $\mathrm{mg} / \mathrm{L}$ & $<500$ & $500-2,000$ & $>2,000$ \\
\hline manganese & $\mathrm{mg} / \mathrm{L}$ & $<0.1$ & $0.1-1.5$ & $>1.5$ \\
\hline iron & $\mathrm{mg} / \mathrm{L}$ & $<0.1$ & $0.1-1.5$ & $>1.5$ \\
\hline hydrogen sulfide & $\mathrm{mg} / \mathrm{L}$ & $<0.5$ & $0.5-2.0$ & $>2.0$ \\
\hline bacterial populations & max. $\mathrm{number} / \mathrm{L}$ & $<10,000$ & $10,000-50,000$ & $>50,000$ \\
\hline
\end{tabular}

Source: Hanson et al. 1997. 
the reclaimed wastewater irrigation appeared to only slightly increase the soil compaction and reduce the soil's capacity of holding nutrient elements, such as magnesium.

For the successful application of treated wastewater in agricultural production, growers should consider adjusting nitrogen fertilization and salinity management. Nitrogen in treated wastewater can range from 5 to $20 \mathrm{mg} / \mathrm{l}$ (50 to $200 \mathrm{~kg}$ /ha per meter of water applied) since secondary treatment does not remove nitrogen from the effluent. At the higher concentration, the amount of nitrogen in reclaimed wastewater irrigation can meet the nitrogen requirements of most crops. For cotton, this nitrogen often causes excessive growth later in the season. To correct this problem, growers now use the treated wastewater containing beneficial nitrogen for early-season irrigation and switch to well or canal water with low nitrogen in the later season, or blend the treated wastewater with other waters to reduce the nitrogen input. For the Kern County site, however, concentrations of nitrate-nitrogen are usually below $10 \mathrm{ppm}$ and rarely cause this type of problem.

Another issue for this site is the high salinity and sodicity of the soil, as is the case with over half the city's farmland. To manage this issue, additional leaching is necessary for the field receiving wastewater irrigation. This field is heavily irrigated using flood or furrow irrigation, with gypsum and lagoon scrapings applied every 2 or 3 years to improve infiltration. Due to the extremely low salinity of the Kern River water, gypsum is also occasionally applied to the control field.

Proper management of irrigation with reclaimed wastewater has enabled this farm to achieve successful crop production comparable to irrigating with fresh canal water.

\section{CONCLUSION}

Reclaimed wastewater has been successfully applied in many parts of the world, including the southwestern United States. As demand for high-quality water increases, more agricultural land and landscapes will depend on wastewater as a source for irrigation. Safe and successful application of wastewater involves careful planning of the wastewater application projects, implementation of safety guidelines, and proper management according to the soil, crop, and water characteristics.

\section{REFERENCES}

AAWA (American Water Works Association). 1994. Dual water systems. New York: McGraw-Hill.

ADWR (Arizona Department of Water Resources). 1999. ADWR third management plan, 2000-2010. ADWR Web site, http://www.azwater.gov/dwr/Content/Publications/files/ThirdMgmtPlan/tmp_final/default.htm.

ANZECC and ARMCANZ (Australian and New Zealand Environment and Conservation Council, and Agriculture and Resource Management Council of Australia and New Zealand). 2000. Australian Guidelines for Water Quality Monitoring and Reporting Web site, http://www.mincos.gov.au/publications/ australian_guidelines_for_water_quality_monitoring_and_reporting.

Arcand-Hoy, L. D., and W. H. Benson. 1998. Fish reproduction: An ecologically relevant indicator of endocrine disruption. Environmental and Toxicological Chemistry 17:49-57.

Asano, T. 2007. Water reuse: Issues, technologies, and applications. New York: McGraw-Hill.

Ayers, R. S., and D. W. Westcot. 1985. Water quality for agriculture. FAO Irrigation and Drainage Paper 29. Rome: FAO. FAO Web site, http://www.fao.org/DOCREP/003/T0234E/T0234E00.HTM.

Cantor, K. P., C. F. Lynch, M. E. Hildwsheim, M. Dosemeci, J. Lubin, M. Alavanji, and G. Cruan. 1998. Drinking water sources and chlorination byproducts. I. Risk of bladder cancer. Epidemiology 9:21-28.

CSWRCB (California State Water Resources Control Board). 2003. Recycled Water use in California. Water Resources Control Board Web site, http://www.waterboards.ca.gov/recycling/docs/wrreclaim_attb.pdf.

CWA (Clean Water Act). 1972. EPA Web site, http://www.epa.gov/watertrain/cwa/.

DWR (California Department of Water Resources). 2005. Final California water plan update. DWR Web site, http://www.waterplan.water.ca.gov/previous/cwpu2005/index.cfm.

EPA (U.S. Environmental Protection Agency). 2004. Guidelines for water reuse. EPA/625/R-04/108. Washington, DC: EPA and U.S. Agency for International Development. EPA Web site, http://www.epa.gov/nrmrl/ pubs/625r04108/625r04108.pdf. 
- 2008. Effluent guidelines/aquatic animal production industry/non-water quality environmental impacts. EPA Web site, http://pubweb.epa.gov/waterscience/guide/aquaculture/add/chapter11_508.pdf.

Hanson, B., L. Schwankl, S. Grattan, and T. Prichard. 1997. Drip irrigation for row crops. Oakland: University of California Division of Agriculture and Natural Resources Publication 3376.

Hildesheim, M. E., K. P. Cantor, C. F. Lynch, M. Dosemeci, J. Lubin, M. Alavanji, and G. Cruan. 1998. Drinking water sources and chlorination byproducts. II. Risk of colon and rectal cancers. Epidemiology 9:29-35.

IRWD (Irvine Ranch Water District). 2002. Water resource master plan. Irvine, California.

- 2006. Michelson water reclamation plant final effluent. IRWD Web site, http://www.irwd.com/ WaterQuality/2006RWReport.pdf.

MLIT (Ministry of Land, Infrastructure, and Transport, Japan). 2001. Sewage works in Japan. Tokyo: MLIT.

National Research Council Committee on Hormonally Active Agents in the Environment. 1999. Hormonally active agents in the environment. Washington, DC: National Academy Press.

Nevada Administrative Code, Chapter 445A. NAC Web site, http://www.leg.state.nv.us/nac/NAC-445A. html\#NAC445ASec070.

O’Connor, G. A., H. A. Elliott, and R. K. Bastian. 2008. Degraded water reuse: An overview. Journal of Environmental Quality 37(5):S-157-S-168.

Rhoades, J. D., A. Kandiah, and A. M. Mashali. 1992. The use of saline waters for crop production. FAO Irrigation and Drainage Paper 48. Rome: FAO. FAO Web site, http://www.fao.org/docrep/T0667E/T0667E00.htm.

Richards, L. A., ed. 1954. Saline and alkaline soils. USDA Agriculture Handbook No. 60. Washington, DC: Government Printing Office. USDA-ARS Web site, http://www.ars.usda.gov/Services/docs. htm?docid=10158\&page $=1$.

SNWA (Southern Nevada Water Authority). 2006. Water resource plan. Chapter 3. SNWA Web site, http://www.snwa.com/html/wr_resource_plan.html.

Swan, S. H., R. R. Neutra, M. Wrensch, I. Hertz-Piciotto, G. C. Windham, L. Fenster, D. M. Epstein, and M. Deane. 1992. Is drinking water related to spontaneous abortion? Epidemiology 3:83-3.

Tanji, K. K. 1990. Crop salt tolerance. In K. K. Tanji, ed., Agricultural salinity assessment and management. New York: American Society of Civil Engineers. 262-304.

Tyler, C. R., S. Jobling, and J. P. Sumpter. 1998. Endocrine disruption in wildlife: A critical review of the evidence. Critical Reviews in Toxicology 28:314-361.

Wang, Z., A. C. Chang, L. Wu, and D. Crowley. 2003. Assessing the soil quality of long-term reclaimed wastewater-irrigated cropland. Geoderma 114:261-278.

Westcot, D. W. 1997. Health risks associated with wastewater use. Chapter 2 in Quality control of wastewater for irrigated crop production. FAO Water Reports No. 10. Rome: FAO. FAO Web site, http://www.fao.org/ docrep/W5367E/w5367e04.htm.

WHO (World Health Organization). 2006. Guidelines for the safe use of wastewater, excreta, and grey water. Vol. 2: Wastewater use in agriculture. Geneva, Switzerland: WHO. WHO Web site, http://www.who.int/ water_sanitation_health/wastewater/gsuww/en/index.html.

Xu J., L. S. Wu, W. P. Chen, and A. C. Chang. 2008. Simultaneous determination of pharmaceuticals, endocrine disrupting compounds and hormone in soils by gas chromatography-mass spectrometry. Journal of Chromatography A 1202:189-195. 


\section{English-Metric Conversions}

\begin{tabular}{|c|c|c|c|}
\hline English & $\begin{array}{c}\text { Conversion factor for } \\
\text { English to Metric }\end{array}$ & $\begin{array}{c}\text { Conversion factor for } \\
\text { Metric to English }\end{array}$ & Metric \\
\hline inch (in) & 2.54 & 0.394 & centimeter (cm) \\
\hline foot (ft) & 0.3048 & 3.28 & kilometer (km) \\
\hline mile (mi) & 1.61 & 0.62 & hectare (ha) \\
\hline acre (ac) & 0.4047 & 2.47 & milliliter (ml) \\
\hline fluid oz (oz) & 29.57 & 0.338 & liter (l) \\
\hline quart, liquid (qt) & 0.946 & 1.056 & liter (l) \\
\hline quart, dry (qt) & 1.1 & 0.91 & liter (l) \\
\hline gallon (gal) & 3.785 & 0.26 & cubic meter (m $\left.\mathbf{m}^{3}\right)$ \\
\hline acre-foot (AF) & 1,233 & 0.000811 & gram (g) \\
\hline ounce (oz) & 28.35 & 0.035 & kilogram (kg) \\
\hline pound (lb) & 0.454 & 2.205 & metric ton (t) \\
\hline ton (T) & 0.907 & 1.1 & \\
\hline
\end{tabular}

\section{ACKNOWLEDGMENT}

This material is based on work supported by the Cooperative State Research, Education, and Extension Service, U.S. Department of Agriculture, under Agreement No. 2004-51130-02258.

\section{FOR FURTHER INFORMATION}

To order or obtain ANR publications and other products, visit the ANR Communication Services online catalog at http://anrcatalog.ucdavis.edu or phone 1-800-994-8849. You can also place orders by mail or FAX, or request a printed catalog of our products from

\author{
University of California \\ Agriculture and Natural Resources \\ Communication Services \\ 6701 San Pablo Avenue, 2nd Floor \\ Oakland, California 94608-1239 \\ Telephone 1-800-994-8849 \\ 510-642-2431 \\ FAX 510-643-5470 \\ E-mail: danrcs@ucdavis.edu \\ (C)2008 The Regents of the University of California \\ Agriculture and Natural Resources \\ All rights reserved.
}

No part of this publication may be reproduced, stored in a retrieval system, or transmitted, in any form or by any means, electronic, mechanical, photocopying, recording, or otherwise, without the written permission of the publisher and the authors.

\section{Publication 8357}

ISBN-13: 978-1-60107-609-0

The University of California prohibits discrimination or harassment of any person on the basis of race, color, national origin, religion, sex, gender identity, pregnancy (including childbirth, and medical conditions related to pregnancy or childbirth), physical or mental disability, medical condition (cancer-related or genetic characteristics), ancestry, marital status, age, sexual orientation, citizenship, or service in the uniformed services (as defined by the Uniformed Services Employment and Reemployment Rights Act of 1994: service in the uniformed services includes membership, application for membership, performance of service, application for service, or obligation for service in the uniformed services) in any of its programs or activities.

University policy also prohibits reprisal or retaliation against any person in any of its programs or activities for making a complaint of discrimination or sexual harassment or for using or participating in the investigation or resolution process of any such complaint.

University policy is intended to be consistent with the provisions of applicable State and Federal laws.

Inquiries regarding the University's nondiscrimination policies may be directed to the Affirmative Action/Equal Opportunity Director, University of California, Agriculture and Natural Resources, 1111 Franklin Street, $6^{\text {th }}$ Floor, Oakland, CA 94607, (510) 987-0096. For information about ordering this publication, telephone 1-800-994-8849. For assistance in downloading this publication, telephone 530-754-3927.

An electronic copy of this publication can be found at the ANR Communication Services catalog Web site, http://anrcatalog. ucdavis.edu.

\section{UCER}

REVIEWED This publication has been anonymously peer reviewed for technical accuracy by University of California scientists and other qualified professionals. This review process was managed by the ANR Associate Editor for Land, Air, and Water Sciences. 